\title{
Agricultural productivity in Australia and New Zealand: trends, constraints and opportunities
}

\author{
M. ROBERTSON \\ CSIRO Ecosystem Sciences and Sustainable Agriculture Flagship, PMB5, Wembley PO, WA 6913, Australia \\ Michael.Robertson@csiro.au
}

\begin{abstract}
With increasing focus on global food security it is timely to examine the historical performance of Australian and New Zealand agriculture and assess future prospects. While Australia and New Zealand are minor contributors to world food production, they do contribute significantly to world wheat and dairy exports. In the last 40 years farmers in both countries have sustained linear growth in crop and livestock production per hectare. This has been driven by development and adoption of new technologies, specialisation and higher use of inputs. At the same time there have been adjustments in industries towards economies of scale and substitution of labour with capital. Future productivity gains will rest with continuing improvement in per hectare production as in both countries the prospects for expansion in the area devoted to key commodities are limited (and in many regions declining). If future growth is to be sustained, it will need to be supported by effective R, D and E to both facilitate adoption of current technologies and develop new pathways for productivity improvement. For a range of reasons it is realistic to assume agriculture is moving into a phase where productivity growth will be driven by greater efficiency of use of fixed and variable inputs rather than an increase in input levels. This will occur against a background of climate change, which will place particular stress on industries limited by water supply.
\end{abstract}

Keywords: production, technology, adoption, climate change

\section{Introduction}

There has been a renewed public attention on global agricultural productivity in recent times due to concerns about food security, food prices, the financial viability of farm businesses under rising costs, and declining availability and affordability of critical inputs such as suitable land, labour, energy, water and fertiliser. This focus has also occurred in Australia and New Zealand whose agriculture sectors share many common features. Agricultural production in both countries is currently dominated by family owned and operated businesses, exporting much of their produce on world markets, without substantial government support programs and in a commercial environment where agriculture is a declining contributor to the national economy. Maintaining growth in agricultural productivity, achieved by technology development, on-farm adoption and increased scale, has been necessary to offset the decline in farmers' terms of trade (Mullen 2010). At the same time, systems of production have had to adapt to the growing environmental and animal welfare imperatives imposed by society, through government, on agriculture. Recent analyses have highlighted an apparent slowing in the rate of growth in agricultural production relative to impressive productivity gains over the last 30 years (Mullen 2007). This makes it timely to review recent progress in Australia and New Zealand and gauge prospects for future growth, particularly in the light of future technologies, climate change and government regulation.

The aims of this paper are threefold: (1) summarise historical trends in agricultural production and constraints to further growth, (2) review the historical role of science and technology in sustaining innovation and productivity growth, and (3) analyse future prospects for productivity advances, including the role of science and technology, taking two contrasting industries (grains in Australia, dairy in New Zealand) to highlight the challenges and opportunities. In keeping with the pastoral and agronomic focus of this conference, the scope of the paper is limited to broadacre industries of the agriculture sector and hence excludes intensive industries such as vegetables, fruit, pig, poultry and eggs as well as the extensive rangelands systems found in inland Australia.

\section{Importance of agriculture to the nation and world food production}

While agriculture is deeply embedded in the national psyche of both countries as foundation industries, the contribution of the sector to gross domestic product (GDP), exports, and employment has been declining since the 1960s along with the number of farms and farmers. Agriculture is still a dominant contributor to total exports in New Zealand in comparison with Australia, and farm businesses occupy just over onethird of the New Zealand landscape (Table 1). In Australia, the value of agricultural exports is dominated 
by grains $(25 \%)$, meat $(25 \%)$, dairy $(8 \%)$, wool $(7 \%)$, other crops e.g. cotton, wine, sugar $(28 \%)$, while in New Zealand dairy $(60 \%)$ and meat $(30 \%)$ account for the bulk of agricultural exports.

Against the background of concerns about global food security it is sobering that in 2009 , both countries were minor direct contributors to global food production (Table 2), although significant players in global trade for wheat (Australia) and dairy (New Zealand) (Table 2). Arguably, both countries have been more significant as exporters of technology and knowledge.

\section{Scope for increased area for agriculture}

In both Australia and New Zealand, the prospects for expansion of the area devoted to key commodities are very limited. In Australia, while the growth in area used for wheat continues to rise, mostly at the expense of sheep, the area for other grains has slowed in recent years (Fig. 1). Lack of suitable soils for crop production, shortages of water for irrigated crops such as cotton and rice, the need to maintain enterprise diversity and noncrop phases in rotations are all likely reasons for limited prospects for expansion in the area for grain production.

The high rainfall zone (HRZ) in southern Australia ( $450-800 \mathrm{~mm} / \mathrm{yr}$ ) covers $\sim 20 \mathrm{M}$ ha, of which $\sim 4 \mathrm{M}$ ha are thought to be arable (Zhang et al. 2006). An expansion of crop production into traditional grazing areas in the HRZ is now possible through the development of adapted crop varieties and new agronomic practices to address soil constraints. While such expansion has the potential for significantly increasing profitability and income stability of farming enterprises in the HRZ it is difficult to imagine an expansion of grain production over more than $50 \%$ of the $4 \mathrm{M}$ ha available due to enterprise mix and rotational constraints. It is notable that the total increase in area under grain crops over the last 40 years has been about $8 \mathrm{M}$ ha. Another $2 \mathrm{M}$ ha from the HRZ devoted to grain production would maintain this impetus for a further decade or so.

In recent times, as water constraints for agriculture in southern Australia have become more acute, attention has turned to northern Australia. An analysis by a government taskforce (Webster et al. 2009) concluded that while there are potentially ca $17 \mathrm{M}$ ha of soils suitable for annual crops and as much as $\sim 32 \mathrm{M}$ ha suitable for forestry, there is probably only water sufficient to exploit ca $60000-120000$ ha, or less than $1 \%$ of this potential via irrigation. Groundwater appears to be the source of water most likely to sustain new development of irrigated agriculture in northern Australia. Whereas surface water favours development of a small number of centralised irrigation schemes (such as the Ord River Irrigation Area), groundwater is best suited to supporting a larger number of small scale and widely dispersed irrigation developments.

In New Zealand, increases in pastoral production will come from intensification of land which is currently in pasture. The land area devoted to pastoral production has declined over the last decade (Moot et al. 2009) and, given the country's topographic constraints; it is unlikely that any new areas will be converted to pastoral agriculture. Intensification is on-going with increasing areas under irrigation, the conversion of sheep and beef farms to dairy production and the more intensive use of easier hill country. In addition, the expansion of forestry, viticulture and horticultural crops will place further constraints on the capacity of New Zealand broadacre agriculture to expand.

\section{Trends in agricultural production}

Farmers in both Australia and New Zealand have responded to the declining terms of trade for their commodities by increasing productivity, often due to higher input levels, changing to higher value outputs and increasing scale (bigger farms, larger herds). There been little deterioration in the terms of trade over the last two decades, which means that farmers (and consumers and processors) have been capturing more of the benefits of productivity growth (Mullen 2010). What follows is a summary of improvements in productivity and efficiency in the main industries of the agriculture sector in both countries.

\section{New Zealand}

New Zealand is recognised for its seasonal, low cost grazing systems matching perennial ryegrass (Lolium perenne)/white clover (Trifolium repens) pasture growth with stock demand. Livestock systems are pasture-based with forage crops and/or conserved feed used to fill in periods when pasture supply is below animal demand. The distance and associated costs of transport between New Zealand and its main export markets, combined with an environment suitable for pastoral production, has resulted in a focus on efficient sheep, beef and dairy production systems (Moot et al. 2010). Each of these industries have responded to these external drivers by changing enterprises and products, increasing productivity per head and per hectare, and restraining costs (Table 3). Total sheep numbers have decreased from 70.3 million in 1982 to 32 million in 2009. This decrease represents the dynamic nature of the livestock industry which has responded to low sheep meat and wool prices and successive east coast droughts. Changes in land use have included conversion of sheep farms to dairying, viticulture and cropping, which offered higher returns than meat. For example, dairy conversions occurred on 330 sheep and beef properties in 2008 which displaced 
Table 1 Contribution of the agriculture sector to New Zealand and Australia at farm gate (Source: Figures are for 2009. ABARE, New Zealand Meat and Wool Economic Service).

\begin{tabular}{lcc}
\hline & New Zealand & Australia \\
\hline Area of country (M ha) & 27 & 770 \\
Land mass devoted to agriculture (\%) & 37 & $6^{\star}$ \\
Gross value of farm production (\$B) & 6.5 & 45 \\
Contribution to total exports (\%) & 48 & 14 \\
Contribution to employment (\%) & 7 & 3.4 \\
Contribution to GDP (\%) & 5 & 2.5 \\
Farm production exported (\%) & 90 & 70 \\
Number of farms & 70000 & 140000 \\
Expenditure on agricultural R\&D (\% of GDP) & 2 & 3 \\
\hline
\end{tabular}

${ }^{*}=$ excluding extensive grazing systems, ${ }^{* *}=$ J. Mullen (pers.comm.).

Table 2 Contribution of selected agricultural commodities in New Zealand and Australia to annual global production (Mt), 20082009 (Source: ABARE, New Zealand Meat and Wool Economic Service).

\begin{tabular}{lcccccc}
\hline Commodity & Global & $\begin{array}{c}\text { Production } \\
\text { \% Australia }\end{array}$ & \% New Zealand & Global & $\begin{array}{c}\text { Exports } \\
\text { \% Australia }\end{array}$ & \% New Zealand \\
\hline Wheat & 687 & 3 & $<0.1$ & 132 & 10 & 0 \\
Red meat & 70 & 4 & 2 & 16.3 & $8^{\star}$ & 5 \\
Milksolids & 438 & 2 & 3 & $1.2^{\star *}$ & 10 & 21 \\
Butter & 8 & 1 & 5 & 0.7 & 10 & 53 \\
Cheese & 14 & 3 & 2 & 1.25 & 12 & 22 \\
\hline
\end{tabular}

*=excluding live exports, ${ }^{* *}=$ skim milk

Table 3 Selected measures of recent productivity improvement in pastoral industries in New Zealand (Source: New Zealand Meat and Wool Economic Service).

\begin{tabular}{|c|c|c|c|c|}
\hline & Industry Change & Percent/ year & Period & Comments \\
\hline \multicolumn{5}{|l|}{ Lamb } \\
\hline Lambing percentage & from 100 to $120 \%$ & 1.0 & 1981 to 2009 & Slowdown since 2007 \\
\hline Lamb carcass weight & from 6 to $7.5 \mathrm{~kg}$ & 2.1 & 1992 to 2004 & \\
\hline $\begin{array}{l}\text { Lamb carcass weight per } \\
\text { ewe }\end{array}$ & from 13 to $17 \mathrm{~kg}$ & 3.1 & $1998 / 9$ to $2008 / 9$ & \\
\hline Price received & $74 \%$ increase & 5.3 & $1985 / 9$ to $1999 / 03$ & $\begin{array}{c}\text { Despite world price falling } \\
\text { by } 12 \%\end{array}$ \\
\hline \multicolumn{5}{|l|}{ Dairy } \\
\hline Stocking rate & from 2.5 to 2.8 cows/ha & 0.8 & $1992 / 3$ to 2008 & \\
\hline Production per cow & $3.9 \mathrm{~kg} \mathrm{MS} / \mathrm{cow} /$ year & 0.6 & $1992 / 3$ to $2006 / 7$ & \\
\hline Production per hectare & $16 \mathrm{~kg} \mathrm{MS} / \mathrm{ha} /$ year & 1.8 & $1992 / 3$ to $2007 / 8$ & \\
\hline Average herd size & $\begin{array}{c}\text { from } 180 \text { to } 351 \text { cows/ } \\
\text { herd }\end{array}$ & 7.3 & $1992 / 3$ to $2006 / 7$ & \\
\hline Price received & from $\$ 3$ to $6 / \mathrm{kg} \mathrm{MS}^{*}$ & 10 & $1999 / 00$ to $2009 / 9$ & $\begin{array}{c}\text { Spikes in 2000-02 and } \\
2006-08\end{array}$ \\
\hline Labour productivity & $\begin{array}{c}\text { from } 85 \text { to } 135 \text { cows/ } \\
\text { FTE }^{\star *}\end{array}$ & 3.4 & $1990 / 1$ to $2008 / 9$ & \\
\hline \multicolumn{5}{|l|}{ Wool } \\
\hline Production per head & from 5 to $6 \mathrm{~kg} / \mathrm{head}$ & 1.7 & 1992 to 2004 & \\
\hline Price received & $40 \%$ decrease & -2.7 & $1985 / 9$ to $2000 / 04$ & \\
\hline
\end{tabular}

${ }^{*}=$ milksolids, ${ }^{* *}=$ full time equivalent labour unit 
Figure 1 Time trend of area used to grow wheat and other crops in Australia (Source: ABARE).

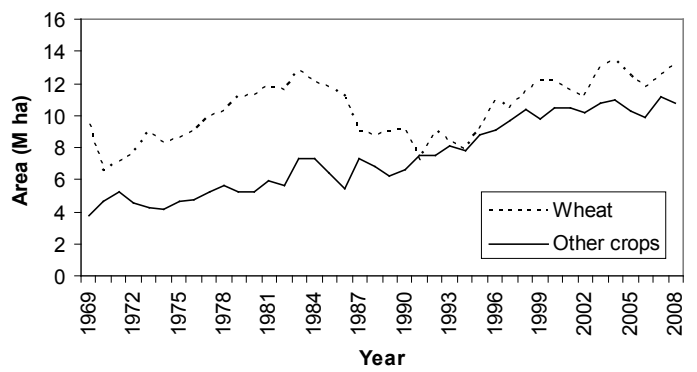

1.3 M sheep and beef stock units. Despite the decline in sheep numbers since 1990, total national lamb meat production has increased by $12 \%$ over the same period. Productivity improvements have been underpinned by a sustained annual increase of $1-3 \%$ in lambing percentage, higher carcass weights, and lamb produced per ewe (Table 3). This reflects improvements in onfarm management practices, genetic gains for animals and pastures (Woodfield \& Easton 2004), higher quality pastures, animal and pasture based research and uptake of new knowledge by pastoral farmers. At the same time, a shift towards higher value output (chilled rather than frozen meat), has increased prices received by farmers in the face of a decrease in the international price for lamb during the 1990s and early 2000s (Cocks $\&$ Brown 2005, Table 3). A decrease in the wool price since $2005 / 2006$ has also resulted in a shift by farmers towards composite sheep breeds to increase income from meat production with the wool component now contributing less to total farm income.

New Zealand's dairy industry has expanded rapidly over the last 20 years, with the national herd doubling between 1980 and 2009. Traditionally, dairy farming was restricted to 'summer safe' flat to rolling land in the west of the North Island where mean annual rainfall is $\geq 2000 \mathrm{~mm} / \mathrm{yr}$. Recent expansion has occurred into higher risk regions that receive $600-1000 \mathrm{~mm}$ rainfall; these areas and are highly reliant on access to irrigation in summer months. The conversion of sheep/beef properties to dairy has been fuelled by an increase in dairy commodity prices (Table 3 ) as international demand has increased. Increases in dairy productivity has been due to a combination of larger economies of scale (larger herds), increased productivity per head, per hectare and per labour unit and higher prices received (Table 3), with the largest shifts being in herd size and labour productivity. Labour productivity has increased due to substitution of capital for labour (rotary dairy platforms, automatic cup removers, improved cleaning equipment). The increased production per hectare has been due to equal contributions from higher stocking rates and higher production per cow and would not have been possible without an almost concomitant increase in inputs, viz. imported feed, fertiliser nitrogen and irrigation (Newman 2010). Agronomy has contributed through improved forages, especially maize (from overseas) and ryegrasses with better endophytes for plant persistence and animal health (Woodfield \& Easton 2004).

\section{Australia- crops}

In the Australian arable crops sector, all major grain crops have been increasing in yield per hectare at 2-3 $\%$ per year since records began by ABARE in the early 1960s until recently. The exceptions to this trend have been the relatively lower rate in rice ( $1.5 \%$ per year), which has been due to replacement of lower-yielding genotypes, and the relatively higher rate in maize (4.2\% per year). Cotton has shown an annual rate of increase in lint yield per hectare of 5\%. The rates here are similar to global averages of $27 \mathrm{~kg} / \mathrm{ha} /$ year for wheat and 82 $\mathrm{kg} / \mathrm{ha} /$ year for maize between 1990 and 2007 (Fischer $\&$ Edmeades 2010). The recent slowdown in yield gain in the temperate and Mediterranean regions has been attributed to drought (Kokic et al. 2006), although it may also be reflecting that a plateau has been reached in adoption of farming technologies (e.g. low till farming) coupled with greater within and between season variability in rainfall and frost.

Wheat forms just over half of the area devoted to arable crops fluctuating between 11 and 13 million ha since 2000. Since the mid-1970s to 2004 the areas sown to other crops (pulse, oilseeds, cotton, sugar) has grown at around $250000 \mathrm{ha} /$ year but has now also slowed and fluctuates around 8 million ha (Fig. 1). Within the grains industry some noticeable trends include the recent increasing dominance of cereals (wheat and barley) (Fig 2); the decline in area of some break crops (notably lupins and to a lesser extent field peas); the erratic nature of others (notably canola); steady (sorghum, maize) or declining (sunflower) area of summer grains, and steady and minor areas of lentils, faba beans and chickpeas.

What have been the drivers behind such growth in the Australian grains industry? Increased understanding of cropping systems is the most frequently advanced reason for strong productivity growth in the 1980s and 1990s (Jackson 2010). This directly contributed to productivity growth by allowing farmers to make better decisions and, hence, use inputs more effectively to produce outputs (Kokic et al. 2006). Practices include effective use of crop rotations, increases in fertiliser and ameliorant use, reduced tillage, and changes to cropping practices such as integrated weed management. New component technologies that have contributed to the productivity improvements include greater disease 
Table 4 Selected measures of productivity (yield/ha harvested) improvement in arable and pastoral industries in Australia (Source: ABARE).

\begin{tabular}{|c|c|c|c|c|}
\hline & $\begin{array}{l}\text { Rate of linear } \\
\text { increase }\end{array}$ & $\begin{array}{l}\text { Percent } \\
\text { per year }\end{array}$ & Period & Comments \\
\hline \multicolumn{5}{|l|}{ Grains } \\
\hline Wheat & $27 \mathrm{~kg} / \mathrm{ha} /$ year & 2.3 & $1970-2000$ & slowdown since 2001 \\
\hline Barley & $24 \mathrm{~kg} / \mathrm{ha} /$ year & 2.4 & $1962-2001$ & slowdown since 2002 \\
\hline Oats & $26 \mathrm{~kg} / \mathrm{ha} /$ year & 2.5 & $1962-2001$ & slowdown since 2001 \\
\hline Sorghum & $32 \mathrm{~kg} / \mathrm{ha} /$ year & 2.1 & $1962-2008$ & \\
\hline Maize & $92 \mathrm{~kg} / \mathrm{ha} /$ year & 4.2 & $1962-2008$ & \\
\hline Rice & $88 \mathrm{~kg} / \mathrm{ha} /$ year & 1.5 & $1968-2005$ & slowdown since 2006 \\
\hline \multicolumn{5}{|l|}{ Other crops } \\
\hline Cotton lint & $30 \mathrm{~kg} / \mathrm{ha} /$ year & 5.0 & $1964-2008$ & \\
\hline Sugar & $48 \mathrm{~kg} / \mathrm{ha} /$ year & 0.4 & $1962-2008$ & \\
\hline \multicolumn{5}{|l|}{ Beef } \\
\hline Weight at slaughter & $2.2 \mathrm{~kg} / \mathrm{hd} /$ year & 1.5 & $1962-2008$ & \\
\hline \multicolumn{5}{|l|}{ Lamb } \\
\hline Weight at slaughter & $0.19 \mathrm{~kg} / \mathrm{hd} /$ year & 1.1 & $1987-2004$ & slowdown since 2005 \\
\hline Dairy & $82 \mathrm{~L} \mathrm{milk/cow/year}$ & 4.1 & $1962-2008$ & \\
\hline Wool & $\begin{array}{l}\text { No discernible trend in yield per } \\
\text { head }\end{array}$ & - & 1989 to 2009 & $\begin{array}{l}\text { Reduction in diameter of } \\
1.8 \mu \mathrm{m}\end{array}$ \\
\hline
\end{tabular}

Figure 2 Changes in area ( $\mathrm{M}$ ha) of main crop species in the Australian grains industry, 1998-2009 (Source: ABARE).

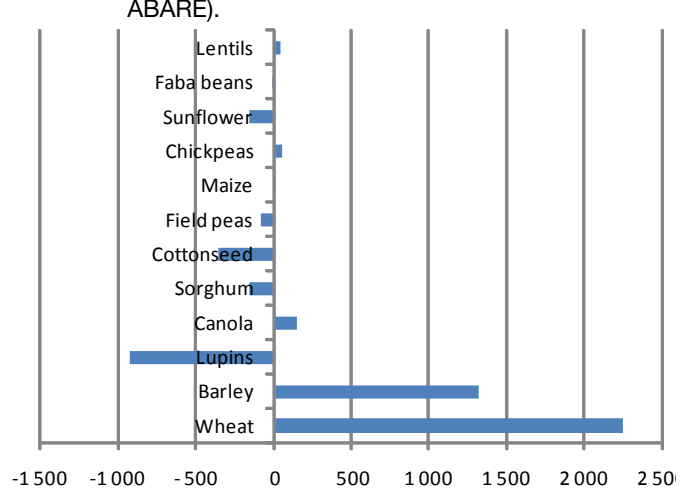

resistance of crop varieties, more efficient chemicals and fertilisers and larger, more sophisticated machinery that has allowed earlier sowing and retention of soil water. Singly they contributed to advances but also in combination they have aided the development of reduced tillage and controlled traffic systems, and have led to more efficient use of labour, fuel and capital and, to a lesser extent, yield improvements (Jackson 2010; Kirkegaard et al. 2010). All of these changes have increased the skills required of farmers, which in turn has increased the use of consultants and agronomists
Figure 3 Trend in volume of Australian crop and livestock production (indexed to 1997-98) (Source: ABARE).

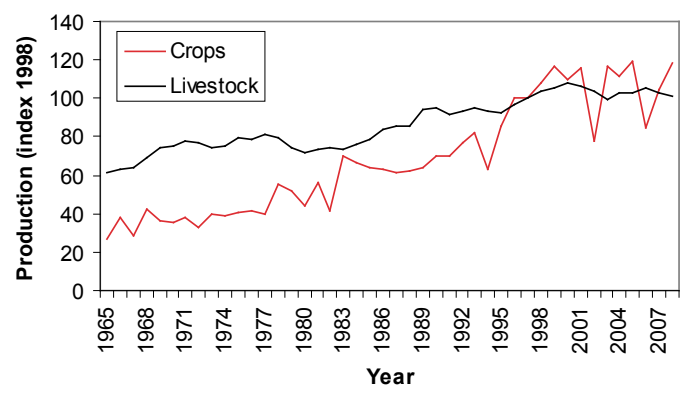

and the managerial capacity of grain growers.

Apart from the direct effect of the recent drought in southern Australia on crop yield, a number of other associated factors contribute to a slowdown in productivity growth. These include lowering farm profits and hence reducing investment in new technology, and reducing the confidence of farmers to the point where many were making sub-profit maximising decisions due to risk aversion. Beyond the direct and indirect effects of drought, other factors must not be discounted. These include: (1) smaller incremental gains from new technology (and fine-tuning of existing technology) compared to the significant 
Figure 4 (a) Trend in fertiliser consumption, and (b) fertiliser, chemical and fuel costs for Australian farms (Source: ABARE).

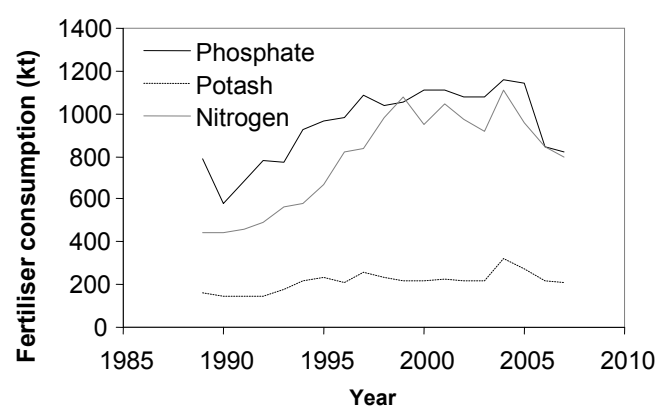

productivity growth delivered by new technology (e.g. reduced tillage systems, GPS based technologies) in the 1980s and 1990s, (2) knowledge gaps now becoming limiting to solving constraints, (3) the poor performance of some ex-grazing land that cropping expanded onto, (4) declining profitability of break crops and associated move to cereal dominance (Lawes et al. 2010; Fig. 2) with related weed, pest, disease and soil fertility problems; and finally (5) the static level in real terms of investment in agricultural R \& D since about 2001 (Mullen 2007).

\section{Australia- livestock}

In a similar trendt to that in New Zealand, the gross returns in Australia from sheep meat and wool are now roughly equal, in contrast to the period $1989 / 1990$ $1991 / 1992$ where wool accounted for about $85 \%$ of the gross value from sheep. Curtis (2009) has estimated that between 11 and $22 \%$ of the increased return from meat has been from selling down the national flock, where sheep numbers have declined from 170 million in 1990 to 71 million in 2009 (beef numbers have remained static around 22-24 million). This change has been associated with a shift to a ewe dominant flock, an increase in lamb production (Table 4), more ewes being joined to terminal sires to produce first cross lambs, an increase in lambing percentage and a reduction in the number of sheep slaughtered for mutton. Like New Zealand several decades ago, the use of more fecund and higher growth rate breeds of sheep today provide increased options for Australian sheep producers to exploit. This restructuring of the industry has meant that the number of lambs slaughtered has increased despite the overall sheep population falling significantly. At its most basic level, the number of lambs born in recent years has been less than the total of lambs slaughtered, sheep slaughtered and live sheep exports, raising concerns that the national flock will continue to shrink. However, it is expected that the rate of decline will be slowed with a switch toward more prime lamb production with associated increase in marking rates as the ewe breed mix changes away from pure Merino. Evidence

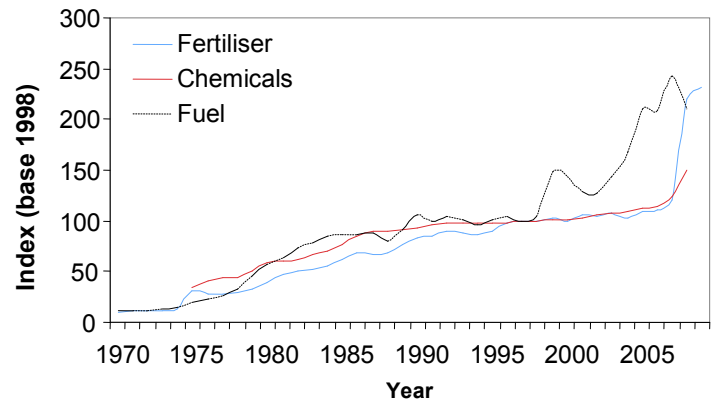

Table 5 Current key agronomic technologies used in the New Zealand dairy industry and the Australian wheat industry and their extent of adoption by farmers. $\mathrm{L}=$ low $(0$ $30 \%$ ), $\mathrm{M}=$ medium (30-70\%), $\mathrm{H}=$ high ( $>70 \%$ ) percent of farmers currently using the technology (Source: Grains Research and Development Corporation Farm Practice Baseline Survey and C. Clark pers. comm.).

\begin{tabular}{lc}
\hline Technology & Adoption status \\
\hline New Zealand dairy & $\mathrm{L}$ \\
Feed budgeting & $\mathrm{H}$ \\
Artificial insemination & $\mathrm{L}$ \\
Regular pasture renovation & $\mathrm{M}$ \\
Irrigation scheduling & $\mathrm{M}$
\end{tabular}

$\begin{array}{ll}\text { Australian grain } & \\ \text { Variable rate technology (fertiliser, } & \mathrm{L} \\ \text { pesticides, ameliorants) } & \mathrm{H} \\ \text { Vehicle guidance } & \mathrm{M} \\ \text { Controlled traffic } & \mathrm{M} \\ \text { Liming } & \mathrm{M} \\ \text { Soil testing } & \mathrm{M} \\ \text { Integrated weed management } & \mathrm{H} \\ \text { Reduced tillage } & \mathrm{L} \\ \text { Seasonally-responsive fertiliser } & \\ \text { management } & \end{array}$

of this has been seen recently where the lambing rate for slaughter lamb producers has risen above $90 \%$ in $2009 / 2010$ for the first time ever. Fewer sheep may well be sold for slaughter as producers maintain their breeding flock and seek income from selling more lambs.

The build-up of the wool stockpile and the subsequent demise of the reserve price scheme in the early 1990s led to a period of sustained downward pressure on wool prices. This was felt most severely in the mid to high diameter range for Merino wool. As a result producers faced declining returns from wool or the decision to reduce the diameter of their clip. Between 1989/1990 and to 2008/2009, the average diameter of all Australian wool sold decreased by about $1.8 \mu \mathrm{m}$. Over the same 
Table 6 Performance of groups of New Zealand owner-operator dairy farms $(n=208)$ ranked by quartile on operating profit $(\$ /$ ha) compared to the Lincoln University dairy farm (LUDF) (Source: DairyNZ Economic Survey 2008-09 and LUDF).

\begin{tabular}{lccccc}
\hline & Bottom & Bottom-middle & Middle-top & Top & LUDF \\
\hline Milking hectares & 136 & 114 & 133 & 124 & 159 \\
Cows & 384 & 313 & 360 & 374 & 660 \\
Stocking rate & 2.8 & 2.7 & 2.7 & 3.0 & 4.2 \\
Kg MS/cow & 322 & 331 & 347 & 355 & 415 \\
Kg MS/ha & 911 & 906 & 940 & 1070 & 1722 \\
Operating profit (\$/ha) & -368 & 515 & 1113 & 1958 & \\
\hline
\end{tabular}

Table 7 Future possible contributions of agronomic technology to productivity and profitability gains in the New Zealand dairy industry and the Australian wheat industry.

\begin{tabular}{lll}
\hline & New Zealand dairy & Australian wheat \\
\hline Increase production potential & $\begin{array}{l}\text { Low N requiring legumes and grasses } \\
\text { Overcoming clover-grass competition }\end{array}$ & $\begin{array}{l}\text { Overcoming soil constraints (diagnosis, placement of } \\
\text { ameliorants) } \\
\text { High sugar content grasses }\end{array}$ \\
& & $\begin{array}{l}\text { Break crops that produce effects that persist longer in } \\
\text { the cereal phase }\end{array}$ \\
& & Broadly adapted break crops \\
& & Very early maturing varieties for marginal situations \\
& & Late maturing varieties for high rainfall situations
\end{tabular}

Input management

Information and communication technology
Improved forages, particularly maize Integrated supplementary feed production

Nitrification inhibitors

Remote monitoring and management of animals and pastures

Electronic identification and control of animals

Databases for industry benchmarking Robotic milking
Rapid and cheap soil testing (water, nutrients, root constraints)

Technology for early/dry sowing (tillage, seed priming)

Precise metering and placement of inputs

Accurate short term weather forecasts

Monitoring and mapping of inputs and outputs

Autonomous vehicles period many exited the wool industry. Those that stayed produced finer wool and have been able to soften a decline in income without an increase in price or production (Curtis 2009).

Productivity increases, in terms of multi-factor productivity (MFP, Mullen 2010) and volume of production (Fig. 3), of the grains sector has exceeded that from the livestock sector until recently. Possible reasons for superiority of the grains sector include the greater extent of mechanisation in cropping, faster advances in crop genetics than in animal genetics and greater scope and incentive to make changes to the technology used in crop production. The swing towards cropping on mixed farms has also allowed farmers to take advantage of economies of scale and to utilise soil nutrients accumulated while the land was used for grazing. Reducing livestock numbers has also increased the productivity of cropping enterprises by allowing producers to concentrate more resources on this enterprise. The trend of cropping specialists out-performing livestock producers appears to have reversed for the past 10-15 years because of improvements in the livestock sector in response to higher prices, combined with a decline in cropping and effects of the drought hitting crop more than livestock production. On top of these average trends there has recently been a much greater influence of seasonal variability on grains compared to livestock (Fig. 3). Technologies contributing to the improvements in productivity for livestock include the use of crossbred sheep genetics with resulting greater meat production, improved pasture and forage varieties, and improved feedbase management leading to better nutrition and livestock performance (Anon 2009).

\section{Australia - numbers of farms and farmers}

As in New Zealand, farm size has increased as the number of farms has decreased in both the Australian grains and livestock sectors. There has been a $26 \%$ decline in the number of Australian farms producing sheep between 1990 and 2007 and a 19\% loss of grain growers over the same period. Overall the rate of increase in farm size has been about $1 \%$ per year, but has slowed in recent years. The trend towards larger farms not only improves economies of scale but it is linked to productivity per hectare. Knopke $(1995 ; 2000)$ found that larger farms have higher rates of productivity gain than smaller farms and Kokic (2005) showed that costs per hectare were negatively related to farm size and productivity. Larger farms in general use superior 
technology, which allows them to use different, more efficient combinations of inputs than smaller farms. Possible reasons for this may be that new technologies are better suited to larger scale farming and that larger farms have more scope to make changes to the input mix. Larger farms may also have a greater capacity to invest in new technology and practices because of their generally larger cash flow and greater ability to borrow.

Australia's farm sector is in the midst of a demographic shift that, if and when it stabilises, will leave an older and smaller population. The major factors behind this shift are reduced recruitment of younger persons and delayed retirement (Barr 2004). Since 1976 the number of farmers aged 20 to 29 has declined by over $60 \%$. The number of farmers aged over 55 has changed little. These trends are more pronounced in some industries and landscapes than in others. The dairy and cropping industries have maintained a relatively young age profile whilst the majority of those in the beef industry are aged between 50 and 64 . The sheep industry appears to be in a progression towards an older population profile similar to the beef industry (Barr 2004).

\section{Maintaining future productivity increases}

Overall, what can we learn from productivity trends over the last 30 - 50 years in Australia and New Zealand and what prospects are there for the future? The dairy industry in New Zealand and grains industry in Australia are good examples where almost linear increases in production have been due to growth in the use of inputs, increase in economies of scale, substitution of labour with capital and increased specialisation.

Productivity in the sheep meat industries of both countries have been under-pinned by improvements in animal genetics, feeding, pasture management and marketing, with gains in Australia emerging much later than those in New Zealand. The greater focus on lamb production by former wool-meat producers has also contributed to gains.

In the grains industry of Australia, it is tempting to conclude that we have passed an era where productivity increases were relatively easily gained through increased inputs (Fig. 4a) and step changes to farming practices and that future gains will be harder to achieve. A major concern is whether drought, and any increased frequency/severity of dry periods under climate change, will stifle future productivity growth (Mullen 2007). Impacts will be felt in the irrigated sector if continued droughts and/or the politics of water result in reduced water allocations. In the dryland sector, adapting to a drier environment will require a greater emphasis on soil water conservation and risk management.

Growth in the New Zealand dairy industry will likely come from further expansion onto former sheep land in marginal rainfall environments, supported by increased irrigation and integration of more cropping as fodder support. There is further scope for consolidation into larger herds whilst mechanisation of milking and animal management will drive gains in efficiency of labour use. However, increased herd sizes can have implications for the energy efficiency of feeding systems and increased environmental problems caused by greater concentrations of waste.

In all sectors of both countries, rising costs of inputs (e.g. Fig. 4b) mean that emphasis must shift to making more efficient use of existing or smaller levels of inputs rather than increasing the overall level of inputs.

Finally, society's concerns about the impact of agriculture on the environment and animal welfare will place increasing constraints on what farmers can and cannot do - whether this is limiting nitrogen losses, reducing greenhouse gas emissions, minimising soil loss or protecting animal well being. This has been obvious in New Zealand, where concerns about $\mathrm{N}$ and $\mathrm{P}$ losses to surface and groundwater have resulted in regulatory frameworks to control nutrient management; and in Australia where concerns in the market over mulesing of sheep have dramatically impacted the Merino industry.

Much of the gain in productivity in both Australia and New Zealand over the last 30 years has come about through increasing scale and mechanisation. The rising cost of rural land and concerns about climate and market volatility means that farmers may be constrained in how much money they can borrow and hence how much bigger they can get. There will also be limits to how much labour can be replaced, although robotics, autonomous vehicles and remote control of animals will offer some gains here. Many believe that there are significant unrealised gains in new business models that will make more efficient use of resources. For example, the sheep and beef sector in New Zealand is moving to stratification whereby "unfinished" stock from hill country farms are supplied on contract to lowland farms for finishing to slaughter (Moot et al. 2010). This creates more secure returns for both types of farms and is being accelerated by large companies that own a range of properties in wet and dry districts that effectively utilise pasture grown at their various properties. In Australia, the idea of separating ownership from management for land, livestock and machinery is gaining traction. For example, in the grains industry share-farming is being seen as a viable alternative, particularly now that there are dedicated companies, providing professionally managed sharefarming opportunities. The on-going stratification of the beef industry into specialist production, backgrounding and finishing enterprises provides opportunities for faster rates of technology adoption, which also has the potential for greater adoption by the sheep industry. 
Table 8 Assumptions used in calculations of projected yield increase in the Australian wheat industry. Groups refer to segments of the farmer population.

\begin{tabular}{|c|c|c|c|}
\hline & Top group & Middle group & Bottom group \\
\hline Initial percent of total farmer population & 25 & 50 & 25 \\
\hline Baseline yield (t/ha) & 2.5 & 2.0 & 1.5 \\
\hline \multicolumn{4}{|l|}{ Annual increase in yield per hectare } \\
\hline Due to genetic improvement alone & $1 \%$ & $0.75 \%$ & $0.5 \%$ \\
\hline \multicolumn{4}{|c|}{ Due to agronomic interventions and contributions } \\
\hline Variable rate technology & $0 \%$ & $1 \%$ & $0 \%$ \\
\hline Increased available soil water & $2.3 \%$ & $0 \%$ & $0 \%$ \\
\hline Technologies for early sowing & $0.1 \%$ & $0 \%$ & $0 \%$ \\
\hline Overall net improvement & $2.5 \%$ & $1.8 \%$ & $0.5 \%$ \\
\hline
\end{tabular}

Table 9 Assumptions used in calculations of projected milksolids yield increase in the New Zealand dairy industry. Groups refer to segments of the farmer population.

\begin{tabular}{|c|c|c|c|}
\hline & Top group & Middle group & Bottom group \\
\hline Initial percent of total farmer population & 25 & 50 & 25 \\
\hline Baseline yield (kg MS/ha) & 900 & 950 & 1000 \\
\hline \multicolumn{4}{|l|}{ Annual increase in yield per hectare } \\
\hline Due to plant and animal genetic improvement alone & $1.2 \%$ & $1 \%$ & $0.8 \%$ \\
\hline \multicolumn{4}{|l|}{ Due to agronomic interventions and contributions } \\
\hline Feed budgeting & $0 \%$ & $1.5 \%$ & $0 \%$ \\
\hline Precision cow feeding and milking & $0.6 \%$ & $0 \%$ & $0 \%$ \\
\hline High sugar grasses & $0.1 \%$ & $0 \%$ & $0 \%$ \\
\hline Overall net improvement & $1.9 \%$ & $2.5 \%$ & $0.8 \%$ \\
\hline
\end{tabular}

This allows the scale of farmed area to be adequate so that fixed costs are reduced on a per hectare basis and plant investment per hectare is reduced.

\section{Role of current technology in maintaining future productivity growth}

Future productivity increases will be a consequence of on-going adoption and fine-tuning of existing technology as well as developing new technology. Table 5 lists my assessment of the key current agronomic technologies (i.e. excluding genetic improvement of plants and animals) driving productivity in the New Zealand dairy and Australian grains industries. Such technologies vary in their current extent of adoption by farmers either because of their history of development or ease of adoption. Future gains in productivity will be aided by facilitating full adoption of those technologies rated as low and medium, as well as refining those already with high levels of adoption.

There remains a large gap (in many cases four-fold) between the production (and economic) performance of the top farmers and others, suggesting that there are gains to be made in lifting productivity using existing technology. An illustration of this is the large range in biophysical performance, associated with operating profit, amongst owner-operator dairy farms in New
Zealand, and the commercially-run Lincoln University dairy farm. Key points of note from this example are the variation in level of input use (land, fertiliser, livestock, machinery), efficiency of use and production. This suggests that considerable productivity and profitability gains are possible with existing technology.

\section{Role of future technology in maintaining future productivity growth}

When it comes to future technologies (Table 7), many of which are the subject of current R \& D in Australia and New Zealand, it is my assessment that gains will accrue in not only increasing potential production and management of inputs but that enabling technology such as information and communication technology will be critical. A mixture of basic and applied research will be required.

To assess the likelihood of maintaining productivity growth I have conducted a simple set of illustrative calculations for the Australian wheat industry (Table 8 ) and New Zealand dairy industry (Table 9). Current rates of production increase are segmented by farmer class. Each group is assumed to adopt current and new technology at specified rates over 30 years. Category 1 technologies currently exist and have already been adopted by top performing famers. Category 2 and 3 
technologies are assumed to be developed and adopted over 10 and 20 years, respectively. As the "top" group of farmers has already adopted category 1 technologies, gains for this group will be made through adopting category 2 and 3 options as they are developed. Productivity gains in the "middle" group are only via full adoption of category 1 technology over the next 10 years, while the "bottom" group only makes gains through the background rate of genetic improvement, i.e. they do not adopt any new agronomic technologies. The benefits of each technology is quantified in production, or production equivalents $(\mathrm{t} / \mathrm{ha})$ if the benefit was a saving on inputs. In both examples, it is assumed the "top" group absorbs $0.5 \%$ of the farmers in the "bottom" group per year due to farm consolidation (the number of farms have been falling by $1 \%$ per year in Australia).

It is assumed that productivity increases above that due to breeding (Fischer \& Edmeades 2010) will come from (1) greater adoption over 10 years of a category 1 practice currently at $20 \%$ adoption (e.g. variable rate technology) and delivering $\$ 20 /$ ha (equivalent to $0.1 \mathrm{t} /$ ha), (2) development and adoption over 10 years of a category 2 practice that increases available soil water by $10 \mathrm{~mm}$ (equivalent to $0.15 \mathrm{t} / \mathrm{ha}$ ), e.g. amelioration of a soil constraint, (3) development and adoption over 20 years of a category 3 practice that allows sowing to occur 5 days earlier on average (equivalent to $0.05 \mathrm{t} /$ ha). Using these fairly conservative assumptions, a weighted yield increase over 30 years of $2.4 \%$ per year is projected. Given that the gains assumed here are unlikely to accrue every year due to (greater) seasonal variability, then $2 \%$ per year, a continuation of the recent historical trend, is probably not an unrealistic target.

In the New Zealand example, productivity increases above that due to pasture breeding (Woodfield \& Easton 2004) and better animal genetics (MacDonald et al. 2008) are assumed to come from: (1) the category 1 practice of full adoption of feed budgeting over 7 years from a current $20 \%$ of farmers bringing about 9\% more milk production per cow (Fulkerson et al. 2004), (2) a category 2 practice of "precision" feeding and milking tailored to individual cows giving 5\% improvement when developed and adopted over 15 years, (3) a category 3 technology of high sugar grasses, developed and adopted over 20 years, which result in better conversion of protein to milk of $2 \%$. Using these assumptions a weighted yield increase of $2.2 \%$ per year is projected. This is a continuation of the historical trend and is probably also not an unrealistic industry target.

Note that both these examples do not assume an increase in the use of inputs, just more efficient use of current levels of inputs, and hence probably underestimate the true gains possible. While the calculations are essentially illustrative, the approach does demonstrate how some simple assumptions about adoption in combination with estimates of the benefits from current and new technology can provide estimates of the feasibility of maintaining productivity gains into the future.

\section{Climate change}

Much has been written and said elsewhere about climate change and agriculture; suffice to say here that it is a significant source of uncertainty, particularly around the impact on timing and amount of rainfall for plant production. Current projections provide us with more certainty around the future rate of rise of temperature and atmospheric carbon dioxide concentrations.

In Australia, managing climate variability has been a significant theme in agricultural research and development in the past and will remain so in the future in the face of climate change. Projections indicate that by 2030 , southern Australia may receive up to $10 \%$ less rainfall while northern areas see changes of -10 to $+5 \%$. By 2050 , southern areas may get up to $20 \%$ less rainfall, with changes of -20 to $+10 \%$ in the north (Stokes \& Howden 2010). Water security problems are projected to intensify by 2030 in southern and eastern Australia as a result of reduced rainfall and higher evaporation. Modest reductions in rainfall will result in significant reductions in water availability for agriculture in the Murray Darling Basin, the chief irrigated area and contributor of about one third of the gross value of production for Australian agriculture. Many of the adaptation options being discussed are extensions or enhancements of existing activities that are aimed at managing the impacts of existing climate variability (Stokes \& Howden 2010). A challenge for Australian agronomists is to identify those additional options that require research and development, and for climate scientist to provide more accurate and reliable within and between season climate forecasts, especially rainfall.

In New Zealand, Wratt (2009) predicted more rainfall on the west coast while eastern areas will be warmer and drier with more variable seasons. In summer-moist regions this will mean greater pasture growth in winter but more stress for temperate species in the summer and hence greater calls for $\mathrm{C}_{4}$ species that currently are confined to warmer regions. In summer-dry regions, summer/autumn water deficits are predicted to worsen, raising concerns about the persistence of white-clover based pastures and the need to grow more droughttolerant species such as lucerne and annual clovers. It would seem, in general, that fitting of existing pasture germplasm to new climates will be able to overcome many of the anticipated challenges from a changing 
climate. Of greater, and more immediate, concern to the sector is the challenge of adapting to the recently legislated emissions trading scheme.

\section{Conclusions}

While Australia and New Zealand are minor contributors to world food production, farmers in both countries have over recent decades sustained linear increases in crop and livestock production. At the same time there have been adjustments in industries towards economies of scale, mechanisation, specialisation, and higher use of inputs. For a range of economic, regulatory and risk reasons we are moving into a phase where productivity growth will be driven by greater efficiency of use of fixed and variable inputs. The role of technology in driving productivity increase is indisputable and some cautious assumptions support the idea that productivity should continue to increase at about $2 \%$ per year. If this is to be realised, it will be essential for effective R, D and E to both facilitate adoption of current technologies and develop new pathways for productivity improvement.

\section{ACKNOWLEDGEMENTS}

This paper has benefited from constructive input from a number of colleagues from both sides of the Tasman: Rob Kelly, John Kirkegaard, Peter Carberry, Rick Llewellyn, John Angus, John McIvor (CSIRO), Jim Scott (University of New England), John Mullen (Charles Sturt University), Derek Wilson (Plant and Food Research), Derrick Moot (Lincoln University) and Cameron Clark (DairyNZ).

\section{REFERENCES}

Anon. 2009. National Sheepmeat Production RD\&E Strategy for Australia pp.58

Barr, N. 2004. The demographic transition of the Australian farm sector. 12th Biennial Conference of the Australian Population Association, 15-17 September 2004, Canberra.

Cocks, J.; Brown, C. 2005. Long-term analysis of price, productivity and profitability trends in New Zealand agriculture. Proceedings of the New Zealand Grasslands Association 67: 9-17.

Curtis, K. 2009. Recent changes in the Australian sheep industry (the disappearing flock). Report for the Department of Agriculture and Food Western Australia.

DairyNZ (2010). DairyNZ Economic Survey 20082009.

Fischer, R.A.; Edmeades, G.O. 2010. Breeding and cereal yield progress. Crop Science 50: S85-S98.

Fulkerson, W.J.; McKean, K.; Nandra, K.S.; Barchia, I.M. 2004. Benefits of accurately allocating feed on a daily basis to dairy cows grazing pasture. Australian
Journal of Experimental Agriculture 45: 331-336.

Jackson, T. 2010. Harvesting productivity: ABAREGRDC workshops on grains productivity growth, ABARE research report 10.6 to the Grains Research and Development Corporation, Canberra, May.

Kirkegaard, J.A.; Peoples, M.B.; Angus, J.F.; Unkovich, M.J. 2010. Diversity and evolution of rainfed farming systems in Southern Australia. Diversity and evolution of rainfed farming systems in southern Australia. In: Rainfed Farming Systems. Eds. Tow, P.; Cooper, I.; Partridge, I.; Birch, C. Berlin: Springer (In Press).

Knopke, P.; Strappazzon, L.; Mullen, J.D. 1995. Productivity growth: total factor productivity on Australian broadacre Farms. Australian Commodities 2: 486-497.

Knopke, P.; O’Donnell, V.; Shepherd, A. 2000. Productivity gains in the Australian grains industry. ABARE Research Report 2000.1, Canberra: ABARE. Kokic, P.; Davidson, A.; Rodriguez, V.B. 2006. Australia's grains industry - factors influencing productivity. Australian Commodities 13: 705-712.

Lawes, R.A. 2010. Using industry information to obtain insight into the use of crop rotations in the Western Australian wheat belt and quantifying their effect on wheat yields. In: Food Security from Sustainable Agriculture. Proceedings of the $15^{\text {th }}$ ASA Conference, 15-19 November 2010, Lincoln, New Zealand.

Macdonald, K.A.; Verkerk, G.A.; Thorrold, B.S.; Pryce, J.E.; Penno, J.W.; McNaughton, L.R.; Burton, L.J.; Lancaster, J.A.S.; Williamson, J.H.; Holmes, C.W. 2008. A comparison of three strains of HolsteinFriesian grazed on pasture and managed under different feed allowances. Journal of Dairy Science 91: 1693-1707.

Meat and Wool New Zealand. 2010. Compendium of New Zealand Farm Facts. 34th Edition. ISSN 1176824X | Publication No. P10013.

Moot, D.; Mills, A.; Lucas, R.; Scott, W. 2010. New Zealand: Country forage/pasture profiles. http://www. fao.org/ag/AGP/AGPC/doc/Counprof/newzealand/ newzealand $1 . \mathrm{htm}$.

Mullen, J.D. 2007. Productivity Growth and the Returns from Public Investment in R\&D in Australian Broadacre Agriculture. Australian Journal of Agricultural and Resource Economics 51: 359-384.

Mullen, J.D. 2010. Agricultural productivity growth in Australia and New Zealand. In: The Shifting Patterns of Agricultural Production and Productivity Worldwide, The Midwest Agribusiness Trade Research and Information Center Iowa State University, Ames, Iowa.

Newman, M. 2010. Lifting productivity on NZ Dairy Farms (unpublished report). DairyNZ. 
Stokes, C.; Howden, S.M. Eds. 2010. Adapting agriculture to climate change: preparing Australian agriculture, forestry and fisheries for the future. CSIRO Publishing: Melbourne.

Webster, T.; Morison, J.; Abel, N.; Clark, E.; Rippin, L.; Herr, A.; Taylor, B.; Stone, P. 2009. Irrigated Agriculture in Northern Australia Land and Water
Science Review, full report. http://www.nalwt.gov.au Woodfield, D.R., Easton, H.S. 2004. Advances in pasture plant breeding for animal productivity and health. New Zealand Veterinary Journal 52: 300-310. Wratt, D.S. 2009. Climate change, climate variability, and the future. Proceedings of the New Zealand Grassland Association 71: 57-59. 